\title{
Exploring Why People Love Their Jobs: A Multi-Industry Case Study
}

Alan D. Smith, (E-mail: smitha@rmu.edu), Robert Morris University Dean R. Manna, (E-mail: manna@rmu.edu), Robert Morris University

\begin{abstract}
Unfortunately, many businesses discuss that rather than valuing people as their most important asset, firms are focusing their efforts on downsizing, outsourcing and taking other actions in order to reduce their labor costs. Instead, developing employee loyalty through inspiring leadership, knockout facilities, and a sense of purpose, management strategically leverages the three most popular traits that employees love about their companies. By questioning HR representatives, managers, and fellow co-workers, the authors were able to determine our own version of the most common traits that employees develop loyalty at Mellon Financial Corporation, the Abreon Group, and the Pine-Richland School District. A number of interesting trends from surveying both administrator and employees of these three diverse settings in Pittsburgh, PA were found. Toxic worry was minimized and loyalty maximized when employees are encouraged to professionally and personally enjoy the people they work with, since this is extremely important to tactical on-time issues with minimum conflict.
\end{abstract}

\section{INTRODUCTION: AGILITY AND RESPONSIVENESS TO EMPLOYEES' NEEDS}

Hallowell (1999) illustrates the missing element of face-to-face communication since newer forms of communications, especially voice-mail and e-mail, have proliferated. The missing face-to-face communication contributes to loneliness and isolation in the workplace and also to the misunderstanding and the percolation of anxiety. In the extreme, trust and respect deteriorate resulting in a dysfunctional organization and decreased competitive advantage. Hallowell touches on many different implications of the newer forms of communications. Toxic worry is a widespread result of these often one-way methods. Toxic worry finds its basis in a lack of the nuances of personal communication such as facial expression, tone of voice, and body language result in people filling in their own conclusions, which could be either correct or incorrect. It is a fact that over $50 \%$ of communication is non-verbal. Thus, newer forms of communication, especially e-mail, carry a great risk of leading to misunderstanding and anxiety as people try to fill in the missing elements so crucial to emotional well being.

Particularly from an employee-based sales and customer service perspective, there is particular agreement with the goal of high tech/high touch. As technology continues taking the place of human-to-human personal interaction, innovative methods must be employed to ensure some form of personal touch is there to satisfy the needs of both employees and customers. Examples of techniques to cater to high touch needs while exploiting advanced communication technology are highlighted in the article. Execution of high tech/high touch can have a powerful and emotional effect on people previously withdrawn and connected only by high tech.

To develop a sense of employee loyalty, many managers exacerbate the tremendous advantages of these new forms of communication by overuse. The instant gratification of communicating at one's leisure leads to micromanaging. Furthermore, the closed loop and documentative nature of e-mail in particular often leads to distrust and suspicion if not supplemented by frequent personal meetings. Managers should refrain from the overuse of these tools when communicating where possible. At the least, a phone call is better than email or voice-mail. Better yet, get out of the office space and develop employee loyalty through interaction. Businesses are experiencing a realistic pattern of how advances in technology designed to enhance communication that actually can 
diminish true communication by making it less rich. Electronic communication is no substitute for being face-toface with another human.

Inspiring leadership, knockout facilities, and a sense of purpose, according to a survey of the best 100 companies, are the three most popular traits that employees love about their company (Lieber, 1998). Even if a particular company does not have any of these traits, the traits bound to have something of interest for most employees. According to Pfeffer, Hatano, and Santalainen (1995), successful companies employ such practices as job security, participation and empowerment, employee ownership, and self-managed teams to name a few. This inspired the authors to take a series of small and personalized surveys of Pittsburgh, PA area firms and find out what employees love about their respective companies (please see Table 1). By questioning HR representatives, managers, and fellow co-workers, the authors were able to determine our own version of the most common traits that employees develop loyalty at Mellon Financial Corporation, The Abreon Group, and the Pine-Richland School District.

Table 1: Sample Of Survey Questions Asked a Number of Companies

\section{For Hr Representatives and Managers:}

1. What makes your company attractive to potential employees?

2. What are your top recruiting techniques?

3. What are the major three to five reasons people want to work here?

4. How long do employees stay here (retention rate)?

5. What are the major three to five reasons people stay here?

\section{For Employees:}

1. Why were you interested in getting a job with the company?

2. What are the top three to five characteristics that you like about working here?

\section{CASE STUDIES}

\section{Mellon Financial Corporation}

Mellon Financial Corporation (MFC) is a global financial company offering services in investment management, trust and custody, foreign exchange, securities lending, defined contribution services, fund administration, stock transfer, proxy solicitation, and cash management, employee benefits consulting, outsourcing services for benefit plans and banking services. In addition, MFC provides products and services related to capital markets, venture capital, loan underwriting and syndications, and real estate finance (www.mellon.com). They currently have 2.8 trillion dollars of assets under management, administration, or custody and employ approximately 300,000 employees worldwide. MFCs headquarters are in Pittsburgh, PA with operations spread across the nation and in other parts of the world such as San Diego, Boston, London, and New York to name a few.

Since MFC is such a large company, we focused on the Global Securities Services (GSS) department:

Mellon Global Securities Services offers premium, worldwide trust and custody and value-added services for the institutional marketplace. Mellon uses a teamwork approach to deliver customized solutions to investment managers, pension funds, insurance companies, not-for-profits, and mutual fund complexes. From core custody, accounting, and cash operations, to superior value-added tools like backoffice outsourcing, performance \& analytics, foreign exchange, benefits disbursements, transition management, internet reporting and processing, commission recapture and securities lending, our clients benefit from Mellon's broad range of product capabilities and commitment to superior customer service. (www.mellon.com). 
However, many of the recruiting techniques and answers by human resources are reflected company wide.

The size of the company and MFCs brand name seems to be what attracts potential employees the most. MFC has ranked among the top five competitors in the industry under various surveys over the past few years. They are also a well-known name in Pittsburgh and among one of the largest employers in the area. Employees mentioned feeling a high sense of job security, which is rare in today's economy. Since selling their consumerbanking division to Citizen's Bank over one year ago, MFC has been able to focus on the more profitable departments such as Global Securities Services.

When asked what employees love about the Advisor Services Group (ASG) department, the most common answer was the people. Those surveyed find comfort by working with friendly people in a laid-back work environment. The nature of the job in ASG demands that employees work closely in teams of three to five people often cooperating to complete tasks and depending on one another to double check one's work and answer each other's questions. Together with the dependency on coworkers, the down-to-earth class of management, and the laid-back environment, employees develop close friendships and a realization that everyone has common goals. Employees do more than just work together. They often socialize outside of work at a local bar, have a day out at the ball game, or even take vacation trips together. Recently, fifteen coworkers rented a house in Deep Creek Lake, Maryland for a weekend getaway.

The second most common answer among employees surveyed is the benefits. MFC, companywide, strives to be the "employer of choice" by offering a wide array of flexible and affordable benefits. Key benefits include a choice of three different medical insurance providers, stock options, affordable life insurance, dental insurance, accidental death and dismemberment insurance, family life insurance, flexible spending accounts for dependent care and health care, tuition reimbursement, and an option to purchase extra vacation time. On top of the choices, MFC also pays for a portion of total benefits costs through the use of flex credits which are determined by the length of time served and an employee's base salary.

Among the honorable mentions, employees love the level of responsibility involved in their jobs. Each team is assigned a group of various investment advisors who manage the trust accounts held at MFC. Teammates are expected to engage in daily activities such as processing trade information correctly, monitoring account cash balances, and ensuring timely settlement of securities transactions entirely on their own. Managers and supervisors are available to offer advice, and help with uncommon or large problems but the day-to-day activities are the sole responsibility of the employee and his or her teammates. According to David Stamps, "Employees should be turned loose to function as independent agents, interacting freely with each other to create new business processes, much the way nature evolves new organisms" (Stamps, 1997). A team in ASG fits this definition of a self-managed team. Employees are often called upon to help management with writing procedures, giving presentations to other employees about new products or processes, and finding new ways to improve upon procedure and automate manual processes. In many aspects, team is structured and forced to follow set procedures. However, given the diversity of investment strategies and account behavior, other team duties involve a few simple rules and allow for the team to be creative and perform tasks differently from other teams.

Human resources representatives spend most of their time at job fares and visiting colleges. MFC saves considerable amounts of time and makes an effort to promote from within the company as much as they can. This means that basically, the only open positions at MFC are entry-level for people straight out of college or looking to get started in a career. They believe that the top factors that attract potential employees are the team-environment and the training. New employees spend four weeks learning the computer programs and learning about the industry before being sent to their work area. From that point, more training is involved through the use of a team environment in which the new employees teammates help him or her settle in to the position by answering questions and teaching unique situations that cannot be seen in a training session. Another key factor is the displacement program. MFC is proud of this program designed to help newly laid-off employees find another position within the company. When one department is closed down or outsourced, MFC instructs other departments to cease hiring from outside of the company until most of the laid-off employees find positions. Although individual departments within MFC share the company wide policies and procedures, many often have their own unique cultural 
environment. In this case, the two departments discussed: Advisor Services Group and Private Wealth Management are very similar, yet very different.

In polling co-workers, supervisors, and departmental vice-presidents about what employees loved the most, two most common responses were: People relationship building and employment security. The Private Wealth Management sector of MFC is divided into many groups. The team members that were interviewed included the Foundation and Endowment Group. The Foundation and Endowment area is divided up between administrators and investment officers, whom all share common relationships with internal and external clientele. The administrators are typically those who provide daily maintenance to the accounts, while the investment officers are the ones responsible for overall portfolio performance. The most intriguing aspect that came up when the two different sides were asked about why people liked MFC was the difference in viewpoints. On the investment advisory side of the business, the most common response was employment security. In the last few years the economy along with the market, has taken drastic hits, and often times investment managers are highly substitutable. The one exception is MFC Financial. The turnover ratio for investment managers in the Private Wealth Management realm are extremely low compared the industry averages. Through strategic leveraging of employment security signals a long-standing commitment by the organization to its workforce" (Pfeffer 1998). This statement could not be anymore clear in the actions of senior management within MFC. According to the investment mangers of the Foundations and Endowment area, the low turnover ratio and the confidence of senior management in their investment mangers are the main reasons they were attracted to and remain loyal to MFC.

In surveying the administrators, their viewpoints were more toward the softer issues. The most reiterated response was the people. In the Foundation and Endowment group there are three Senior Administrators with two portfolio administrators underneath them. Other than focusing on employment security as one of the reasons employees love MFC, they tended to focus more on the human moment. According to Hallowell (1999), the human moment provides the zest and color in the painting of our daily lives; it restores us, strengthens us, and makes us whole. When presented with this excerpt, the senior administrators were in unanimous agreement as to the truth behind that comment by Hallowell. As an Administrator there are many responsibilities in maintaining daily activities for clients, but more importantly there are tremendous strains on the relationship building techniques used. Strong relationships are the number one reasons for retaining clientele, and are the number one focus of all Senior Administrators. When asked about the importance of the relationship between the administrator and the client, the Senior Vice President of the Foundations and Endowments group stated, "the continual process of relationshipbuilding is the one aspect of this business that is stressed above all other, because without it clients would come and go.” MFC Private Wealth Management, formerly MFC Private Asset Management, is one of the industry leaders in the services that they provide, and they want to become the best by hiring the best. This fact is repeatedly driven home with their employees by the actions of Senior Management. By providing employment security and a unique organizational culture, MFC Private Wealth will continue to meet and exceed industry standards when it comes to the quality of the individuals whom they employ.

\section{The Abreon Group}

As a growing company, The Abreon Group (AG) is small, with an employee base of 250. The company has gone through many changes, as it was originally PST, then was acquired by SARCOM and renamed Sarcom Enterprise Education. In October of 2002, the company refocused and rebranded itself as The Abreon Group. Unfortunately, since the IT (information technology) industry has seen so much change, the company's focus and core offerings has shifted from technical training to IT change consulting with competencies in solution architecture, education, communication, and coaching and support.

Considering the company's history of change, it was difficult to get significant employee information. The average employee retention rate is 2.5 years. The longest recorded employee is 12 years, while the shortest is one day. While these are outliers, they indicate that there are varied employee needs and wants, same as in other companies. While 2.5 years is not a long time with a company, it is one year over the average tenure for employees of consulting firms. 
A group of 15 employees were surveyed. Of the three most popular traits that employees' love about their company as defined by Lieber, Inspiring Leadership is the number one reason. Sense of Purpose follows a close second. No one mentioned knockout facilities as a reason for choosing and maintaining their position with the company. The company's facilities in Pittsburgh are two old, historical buildings with several maintenance problems. However, the company is moving in January to a new facility outside of the city. Everyone surveyed mentioned that they are in a position they enjoy and can apply their education, skills and training. Additional reasons include: creative freedom, autonomy in work, people, small size of company, challenges that lead to growth, and opportunities for growth.

According to Kasten's eleven ways to care for and feed talent, managers should, develop and organize after-hours beer bashes and take your team out to lunch (Layne, 2000). Kasten encourages all team members to engage in open, honest conversation, and for leaders to build a climate of trust. This will result in the leader having insight into the minds of the people who make his company hum. He will know about frustration, anger, and apathy before those emotions bubble to the surface, which will allow him to act proactively. AG does operate on this principal. The president is a visionary who puts his people first. The company follows all seven ways to win (Fast Company, 2001) and has truly great leaders.

\section{Pine-Richland School District}

Pine-Richland School District (PRSD) is a fairly large district with about 1000 employees. The school district has changed drastically over the years. In years past, PRSD was not one of the wealthier districts; however, with new middle to upper class housing developments being built in the area; it has become one of the wealthier districts in the area. Many new changes, such as the financial status of the community, the education level of the parents, and the available amount of tax money, were seen in the district. These changes have profoundly affected the overall environment of the schools throughout the district.

Due to public law and restrictions on solicitations on public and governmental property, the authors were unable to get information concerning the overall satisfaction concerning directly from employees. However, as mentioned earlier, the top three traits as to why employees love their companies, inspiring leadership, knockout facilities, and a sense of purpose. A small survey of parents in the area, the majority of the teachers would believe two of the three to be present. "Knockout facilities may be the most persuasive way to tell employees they're valued" (Lieber, 1998, p. 73). In general, employees appreciate any extra efforts employers are willing to make to please their employees. Companies are going to extremes to please employees by altering the workplace by including useful amenities such as: childcare facilities, van pools, on-sight stores, dry cleaners, banks, and up scale athletic facilities; but for a school district it means available technology and equipment. The facilities that PRSD provided the educators were state of the art. The district prided itself in having all the latest technology available for the students and teachers to use. If a teaching tool was not available and a teacher wanted it, the district would do what it took to make it available. This allowed teachers to enhance the education of the students through continued updates in the use of technology as a learning tool. Because the facilities allowed them to do so, teachers could apply what they had learned in their training and development courses.

Sense of purpose is also a trait as to why employees love their companies. For the majority of the teachers, sense of purpose would be the top reason they were there. Most educators at some point in their careers feel a sense of purpose, as they watch their students develop and apply the skills that they have learned. If an educator, at any level, is not feeling a sense of purpose; he or she is in the wrong profession.

The last trait, inspiring leadership, would have depended on the teacher interviewed. Many of the teachers in the high school thought that the leadership was inspiring and many of them felt otherwise. The principal of the school often empowered the employees to make and provide suggestions for the issues that were raised, by encouraging the faculty to engage in conversation and come to a consensus. However, there were a few teachers who were accustomed to being told what was going to be implemented and did not want to be bothered with deciding on issues. The principal often tried to allow people to voice their opinions, but many of them did not wish 
to do so. Therefore, there were some conflicting opinions as to how the leadership should have been leading the school.

However, we believe most of the teachers would have said the reason that they enjoy the profession would have been the human interactions that occurred throughout the school year, not only with colleagues, but also more importantly with the students. As noted by Hallowell (1999), the human moment has two prerequisites, people's physical presence and their emotional and intellectual presence (Hallowell, 1999). Since human engagements require energy and attention, it is all too easy to get side tracked and disengaged from the conversation unless both the physical and intellectual attention is present. Even though the human moment is diminishing in today's business environment where the use of e-mail and other forms of electronic communication are continually increasing, this is not the case and hopefully will never be the case in the profession of teaching. Because human moments help to alleviate some of the unnecessary stress that comes from this uncertainty, which ultimately benefits the employees and the organization, many teachers truly enjoy their profession.

\section{GENERAL CONCLUSIONS AND IMPLICATIONS}

Since Lieber (1998) wrote his article a number of years ago, there have been many changes in business and American society. Based on changes such as stock market shifts, job shortages, the tragic events surrounding the September $11^{\text {th }}$ and its economic and social effects, and the collapse of dot-com companies, businesses are changing. Based on the present study's findings, we have found three different reasons that people love companies. One reason is the size of the company. The size of the companies mentioned range from small to large. Some look at a large company as an advantage because of opportunities to advance and a sense of security that a large company may bring. Others view a smaller company as an advantage because it is easier to be noticed by senior management and a smaller company does not have as much bureaucracy and "red tape" as a larger company.

Another reason may be the type of work. While this is loosely tied in with sense of purpose, this is purpose as it applies to the employee. The employees that were surveyed in the companies included in this paper, all mentioned that they enjoyed the work they were doing, and that they liked that they could use their skills and education. All of these companies employ knowledge workers who respond well and have the know-what, knowwhy and care-why to do their jobs well (Quinn, Anderson, and Finkelstein, 1996). The companies acknowledge this, and employees like this about their companies.

Apparently, the number one reason for continued employee loyalty was people. The workday is extending and people are relying on their coworkers more and more. Professionally and personally enjoying the people one works with is extremely important to getting things done on time, without conflict. So much time is spent with coworkers that social relationships and friendships develop and this is important to the political functioning of an organization.

\section{REFERENCES}

1. $\quad$ Fast Company. (2001, January). "War for Talent II: Seven Ways to Win." Fast Company, 42, 98.

2. $\quad$ Hallowell, E. (1999, January/February). "The Human Moment at Work." Harvard Business Review, 58-66.

3. Layne, A. (2000, November). "The Care and Feeding of Talent." Fast Company, 40. [Online]. Available: http://www.fastcompany.com/lead/lead_feature/act_kasten.html.

4. $\quad$ Lieber, R. (1998, January). "Why Employees Love These Companies.” Fortune, 72-74.

5. Pfeffer, J., Hatano, T., \& Santalainen, T. (1995, February). "Producing Sustainable Competitive Advantage through the Effective Management of People." The Academy of Management Executive, 1, 55-68.

6. Quinn, J., Anderson, P., \& Finkelstein, S. (1996, March/April). "Managing Professional Intellect: Making the Most of the Best." Harvard Business Review, 71-80.

7. $\quad$ Stamps, D. (1997, April). “The Self-Organizing System.” Training, 30-35. 